\title{
Small intestinal bacterial overgrowth in patients with chronic lymphocytic leukaemia
}

\author{
G M Smith, I M Chesner, P Asquith, M J Leyland
}

\begin{abstract}
As part of a study to assess the possible contribution of lymphoid infiltration of the gastrointestinal mucosa to occult blood loss or malabsorption 20 patients with chronic lymphocytic leukaemia (CLL) had a lactulose hydrogen breath test. In 10 cases $(50 \%)$ a small intestinal peak was detected, suggesting small bowel bacterial overgrowth, and this was confirmed in seven patients by the positive culture of jejunal aspirate. Of the patients with a positive hydrogen breath test, radiological examination showed a duodenal diverticulum in two but no anatomical abnormalities in the other cases. There was no evidence of achlorhydria and transit times were normal. There was no difference in the incidence of hypogammaglobulinaemia among those patients with evidence of small intestinal bacterial overgrowth and those without. Seven patients with a positive hydrogen breath test, however, had undetectable secretory piece in their jejunal aspirates whereas this was present in all patients with a normal breath test who had local immunoglobulin concentrations measured $(p<0.05)$, indicating that the small intestinal bacterial overgrowth may be due to impaired local immunity.
\end{abstract}

Bacterial overgrowth of the small intestine is common in primary acquired hypogammaglobulinaemia. ${ }^{1}$ Patients with secondary antibody deficiency, such as patients with chronic lymphocytic leukaemia, have a well documented predisposition to infection, but evidence of bacterial colonisation of the small bowel has not previously been reported.

Iron deficiency, as measured by bone marrow iron stores, seemed to be a common finding in patients with chronic lymphocytic leukaemia (CLL) at this hospital (personal observation). As part of a wider study to assess the possible contribution of lymphoid infiltration of the gastrointestinal mucosa to occult blood loss or malabsorption, ${ }^{2}$ a lactulose hydrogen breath test was performed in a group of patients with CLL. The hydrogen breath test, first described by Bond and Levitt, ${ }^{3}$ is a simple and non-invasive method of detecting intestinal bacterial colonisation. The test was subsequently used specifically for the detection of bacterial overgrowth of the small bowel by Metz ${ }^{4}$ and Rhodes, ${ }^{5}$ who used lactulose.

\section{Methods}

Twenty patients (12 men, eight women, aged 49-79) were studied. According to the prognostic staging system of the International Workshop on CLL, ${ }^{6}$ nine patients had stage A disease, seven stage $B$, and four stage $C$. None of the patients had any evidence of gastrointestinal effects arising from their malignancy at the time of entering the study. The B cell origin of their disease was confirmed by peripheral blood lymphocyte surface marker analysis. Serum immunoglobulins were measured in all patients using laser nephelometry. No patient had received a recent course of antibiotics.

\section{LACTULOSE HYDROGEN BREATH TEST}

The breath hydrogen concentration was measured using a GMI exhaled hydrogen monitor (Gas Measurement Instruments Ltd, Inchinnan Estate, Renfrew, Scotland, PA7 9RG). The subjects were fasted from $9 \mathrm{pm}$ the previous day and breath hydrogen concentrations were recorded at 9 am. After a chlorhexidine mouth rinse $10 \mathrm{~g}$ of lactulose $(20 \mathrm{ml}$ of $50 \%$ solution) was given by mouth and breath hydrogen concentrations were recorded every five minutes for half an hour, then at 15 minute intervals for three hours or more until a definite colonic peak was noted. If the fasting breath hydrogen concentration was greater than 20 ppm the fast was continued until it fell below this figure. A peak hydrogen concentration of greater than $20 \mathrm{ppm}$ occurring more than 15 minutes before the colonic peak was considered to be positive evidence of small intestinal bacterial colonisation.

\section{JEJUNAL ASPIRATE}

A double lumen sump tube was passed in 10 patients, including eight of the patients with a positive hydrogen breath test, and positioned in the jejunum by screening. Gastric contents were first aspirated via the stomach tube and tested for acidity using litmus paper. Jejunal contents were then aspirated into a sterile universal container. In a further seven cases satisfactory amounts of jejunal juice were obtained at endoscopy. Half of this aspirate was immediately sent to the microbiology laboratory and aerobic and anaerobic cultures were set up. Colony counts were performed only if non-respiratory tract organisms were grown. The remaining jejunal aspirate was sent for estimation of immunoglobulin concentrations, including secretory piece. Two assay methods were used. Firstly, concentrations of IgG, IgA, and IgM were measured using a 
Plot of exhaled breath hydrogen after oral lactulose in a patient with $C L L$, showing a small intestinal peak.

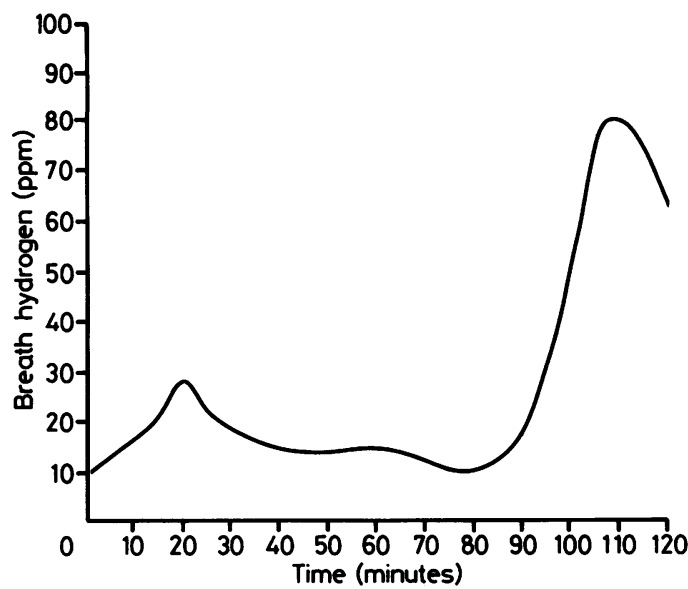

single radial immunodiffusion (Mancini) technique. In view of the possibility of nonimmunoglobulin precipitin rings between antisera and proteolytic enzymes ${ }^{7}$ the results obtained were then confirmed using an Oucherterlony method, which was also used to measure secretory piece.

All patients with a positive hydrogen breath test underwent a small bowel enema looking for any structural abnormalities.

\section{Results}

Ten patients had small intestinal peaks during the lactulose hydrogen breath test. The result from one of these patients is shown in the figure. The mean peak breath hydrogen concentration was $32.7 \mathrm{ppm}$. In all cases the colonic peak was easily distinguishable.

In nine of these 10 patients jejunal juice was available for bacteriological analysis, and in all but one case positive cultures of a variety of organisms were obtained (table 1). In four cases where faecal organisms not normally encountered in the small intestine were grown colony counts showed that they were present in considerable numbers. Previous studies have indicated that colony counts of over $10^{3}$ organisms indicate significant small intestinal contamination. In one further case Staphylococcus aureus was grown in a patient known to be heavily colonised with this organism. Anaerobes were not detected, nor was there
Table 1 Microbiological analysis in nine patients with positive hydrogen breath test

\begin{tabular}{|c|c|c|}
\hline Case No & Colony count & Organism \\
\hline $\begin{array}{l}1 \\
2\end{array}$ & $\begin{array}{r}7.5 \times 10^{5} \\
5 \times 10^{7}\end{array}$ & $\begin{array}{l}\text { Coliforms } \\
\text { Coliforms } \\
\quad+ \\
\text { Faecal streptococci }\end{array}$ \\
\hline $\begin{array}{l}3 \\
4 \\
5 \\
6 \\
7 \\
7 \\
8 \\
9\end{array}$ & $\begin{array}{l}7.5 \times 10^{6} \\
-\quad 10^{8} \\
= \\
- \\
=\end{array}$ & $\begin{array}{l}\text { Coliforms } \\
\text { Coliforms } \\
\text { S aureus } \\
\text { S epidermidis } \\
\text { Mixed flora } \\
\text { No growth } \\
\text { No growth }\end{array}$ \\
\hline
\end{tabular}

evidence of Giardia lamblia.

The small bowel enema showed a single small duodenal diverticulum in two patients, but no anatomical abnormality was seen in the other cases. In two further cases the radiologist commented that peristalsis seemed to be slow, but transit times as measured by the lactulose hydrogen breath test in these patients were normal. ${ }^{8}$

Four of the patients with a positive hydrogen breath test had some degree of hypogammaglobulinaemia (table 2). This was also present, in five out of nine patients with a normal hydrogen breath test. As far as local immunoglobulin production was concerned, in seven patients with a positive hydrogen breath test the secretory component of IgA was not detectable, whereas this was present in all patients with a normal hydrogen breath test in whom local Ig concentrations were measured $\left(\chi^{2}\right.$, using Yates's correction = 4.05; $0.05>\mathrm{p}>0.02)$.

Achorhydria was not detected in any patient.

\section{Discussion}

This study suggests that small intestinal bacterial contamination is common in patients with CLL. In the absence of the recognised risk factors of anatomical abnormality, achlorhydria, recent antibiotic treatment, or reduced motility, ${ }^{9}$ this may be due to impaired immunity. Small intestinal bacterial contamination, and particularly Giardia lamblia infection, is common in patients with hypogammaglobulinaemia and may lead to pronounced malabsorp-

Table 2 Serum and jejunal immunoglobulin concentration in 20 patients with CLL

\begin{tabular}{|c|c|c|c|c|c|c|c|c|}
\hline \multirow[b]{2}{*}{ Case No } & \multirow[b]{2}{*}{ Hydrogen breath test } & \multicolumn{3}{|c|}{ Serum immunoglobulins } & \multicolumn{3}{|c|}{ Jejunal immunoglobulins } & \multirow[b]{2}{*}{ Secretory piece } \\
\hline & & $\operatorname{Ig} G$ & $\operatorname{Ig} A$ & $\operatorname{Ig} M$ & $\operatorname{Ig} G$ & $\operatorname{Ig} A$ & $\operatorname{Ig} M$ & \\
\hline $\begin{array}{r}1 \\
2 \\
3 \\
4 \\
5 \\
6 \\
7 \\
8 \\
9 \\
10 \\
11 \\
12 \\
13 \\
14 \\
15 \\
16 \\
17 \\
18 \\
19 \\
20\end{array}$ & SI peak & $\begin{array}{r}11 \cdot 45 \\
10 \cdot 15 \\
16 \cdot 35 \\
1 \cdot 85 \\
1 \cdot 88 \\
0 \cdot 40 \\
11 \cdot 50 \\
12 \cdot 40 \\
8 \cdot 35 \\
8 \cdot 35 \\
6 \cdot 30 \\
3.95 \\
18 \cdot 80 \\
12 \cdot 60 \\
3.90 \\
4 \cdot 25 \\
6 \cdot 70 \\
5 \cdot 00 \\
7 \cdot 50 \\
8 \cdot 80\end{array}$ & $\begin{array}{l}0.80 \\
1.20 \\
2.30 \\
0.65 \\
0.25 \\
0.15 \\
2.65 \\
1.20 \\
0.55 \\
0.75 \\
0.40 \\
0.30 \\
0.50 \\
2.25 \\
0.30 \\
2.20 \\
0.25 \\
1.05 \\
1.95 \\
1.75\end{array}$ & $\begin{array}{c}0.30 \\
1.35 \\
2.55 \\
0.20 \\
0.50 \\
0 \cdot 10 \\
1.60 \\
0.75 \\
0.25 \\
1.75 \\
0.30 \\
0.06 \\
0.30 \\
0.95 \\
18 \cdot 20^{\star} \\
0.95 \\
0.40 \\
0.45 \\
0.40 \\
0.35\end{array}$ & $\begin{array}{l}0 \cdot 14 \\
\text { ND } \\
0 \cdot 01 \\
0 \cdot 05 \\
\text { ND } \\
\text { ND } \\
\text { Trace } \\
\text { ND } \\
\text { ND } \\
\text { ND } \\
\\
0 \cdot 09 \\
0 \cdot 10 \\
0 \cdot 05 \\
\text { ND } \\
0 \cdot 25\end{array}$ & $\begin{array}{l}0.6 \\
\text { ND } \\
0.02 \\
0 \cdot 10 \\
0.30 \\
0.30 \\
\text { Trace } \\
\text { ND } \\
\text { ND } \\
\text { ND } \\
\\
\\
0.08 \\
0.05 \\
0.05 \\
0.05 \\
0.45\end{array}$ & $\begin{array}{l}\text { ND } \\
\text { ND } \\
\text { ND } \\
\text { ND } \\
\text { ND } \\
\text { ND } \\
\text { ND } \\
\text { ND } \\
\text { ND } \\
\text { ND } \\
\text { Not done } \\
\text { Not done } \\
\text { ND } \\
\text { ND } \\
0 \cdot 05 \\
\text { ND } \\
0 \cdot 15 \\
\text { Not done } \\
\text { Not done } \\
\text { Not done }\end{array}$ & $\begin{array}{l}\text { Present } \\
\text { ND } \\
\text { ND } \\
\text { Present } \\
\text { ND } \\
\text { ND } \\
\text { Present } \\
\text { ND } \\
\text { ND } \\
\text { ND } \\
\\
\text { Present } \\
\text { Present } \\
\text { Present } \\
\text { Present } \\
\text { Present }\end{array}$ \\
\hline
\end{tabular}


tion. ${ }^{1011}$ Patients with B cell neoplasms often have associated hypogammaglobulinaemia which leads to an increased susceptibility to infection. ${ }^{11}$ Evidence of bacterial overgrowth of the small bowel, however, has not previously been sought. A previous study has shown some evidence of malabsorption of fat and folate in a group of patients with CLL and "lymphosarcoma" not primarily of gastrointestinal origin, but no causative mechanism was postulated. $^{12}$ In this study hypogammaglobulinaemia in the serum itself was not associated with small intestinal contamination but there was a consistent abnormality in local Ig production.

IgA is the predominant class of immunoglobulin in the normal small and large intestine and can interfere with bacterial growth by opsonisation, complement fixation, agglutination and the prevention of adherence. ${ }^{13}$ The noticeable absence of intestinal infection in IgA deficiency, however, may suggest that other mechanisms are important in intestinal immunity. ${ }^{14}$ In particular, secretory IgM may have an important role. ${ }^{15}$ In this study there is evidence of local impaired production of secretory piece in seven out of 10 of those patients with small intestinal bacterial overgrowth, and all of these patients also had undetectable jejunal IgM. We have previously reported that occult disease of the gastrointestinal tract is common in patients with B cell neoplasms. ${ }^{2}$ It remains to be seen whether local infiltration of the mucosa is causally related to this impaired immune response.
1 Parkin DM, McClelland DBL, O'Moore RR, et al. Intestinal bacterial flora and bile salt studies in hypogammaglobulinaemia. Gut 1972;13:182-8.

2 Smith GM, Crocker J, Nar P, Chesner I, Leyland MJ. Immunogold-silver technique applied to showing malignant $B$ cell infiltration of the gastrointestinal tract in patients with chronic lymphocytic leukaemia and nonpatients with chronic lymphocytic leukaemia and n
Hodgkin's lymphoma. J Clin Pathol 1987;40:756-9.

3 Bond JH, Levitt MD. Use of pulmonary hydrogen (H2) measurements to quantitate carbohydrate absorption. Study of partially gastrectomized patients. J Clin Invest 1972;51:1219-25.

4 Metz G, Drasar BS, Gassull MA, Jenkins DJA, Blendis LM. Breath hydrogen test for small intestinal bacterial contamination. Lancet 1976; : :668-9.

5 Rhodes JM, Middleton P, Jewell DP. The lactulose H2 breath test as a diagnostic test for small bowel overgrowth. Scand J Gastroenterol 1979;14:333-6.

6 Binet J-L, Catovsky D, Chandre P, et al. Chronic lymphocytic leukaemia: proposals for a revised prognostic staging system. Report from the International Workshop on CLL by the writing committee. Br J Haematol on CLL by the

7 Brown WR. Non-immunoglobulin precipitin lines between intestinal fluids and antisera in immunodiffusion studies: an explanation for their occurrence and how they can be avoided. J Lab Clin Med 1971;77:326-34.

8 Bali A, Stableforth DE, Asquith P. Prolonged smallintestinal transit time in cystic fibrosis. $\mathrm{Br} M e d J$ 1983;287:1011-13.

9 Neale G. Bacteriology of the small gut and bacterial overgrowth. In: Bouchier IAD, Allan RN, Hodgson HJF, Keighley MRB, eds. Textbook of gastroenterology. Keighley MRB, eds. Textbook of gast
London: Baillière Tindall, 1984:487-510.

10 Webster ADB. The gut and immunodeficiency disorders. Clin Gastroenterol 1976;5:323-40.

11 Thelml H, Ziegler-Heitbrock HWL. Management of CLL and allied disorders with reference to their immunology and proliferation kinetics. Recent Res Cancer Res 1984;93:240-58.

12 Pitney WR, Joske RA, MacKinnon NL. Folic acid and other absorption tests in lymphosarcoma, chronic lymphocytic leukaemia, and some related conditions. J Clin Pathol 1960;13:440-7.

13 Shearman DJC, Parkin DM, McClelland DBL. The demonstration and function of antibodies in the gastrodemonstration and function of anti

14 Ross IN, Asquith P. Primary immune deficiency. In: Asquith P, ed. Immunology of the gastrointestinal tract. Edinburgh: Churchill Livingstone, 1979:152-82.

15 Thompson RA. Secretory piece linked to IgM in individuals deficient in IgA. Nature 1970;226:946-8. 